\title{
PECULIARITIES AND DIRECTIONS OF THE WORLD POLITICAL AND IDEOLOGICAL DOCTRINES' EVOLUTION IN MODERN CONDITIONS
}

\section{Natalia Hedikova}

\section{INTRODUCTION}

The process of global changes has always been connected with the changes in the system of traditional values and fundamental socio-cultural principles and their replacement by the new ones. The specifics of these tendencies' manifestation has a number of scientific justifications, but the key one is the discrepancy between the nature of socio-political thought and ideas and concepts that are formed on its basis and are reflected in certain ideologies and processes of social development and civilization as a whole. This is connected with the accelerating rhythm of social development and radical changes which inverse human thinking and being itself. Naturally, these circumstances require new ideas and concepts, while classical ideological trends do not lose their significance. Depending on the historical epoch, national peculiarities, positions of the theorists and actions of political figures and based on their ability to modernize themselves in accordance with specific conditions of the social order, they acquire new, sometimes not inherent from the beginning features, all the time evolving and transforming in the process of adaptation to the real situation.

Ideology, as a socio-political program formed on the basis of the spiritual potential of a particular social group, or of the entire social universe, is a manifestation of their worldview, consciousness and behavior, encompassing all spheres of public life, based on the values, norms and rules adopted by the majority. It is born, formed and modernized through human relationships, conditions and needs for the development of society. Therefore, in the course of their development, and even more often, when implementing different directions of political thought in practice, they often perceive certain elements in completely opposite directions, changing their essence with minimal changes in terminology. In this regard, the division of society into liberals, social democrats, conservatives, etc. is often conditional.

Numerous public opinion polls show that in relation to different aspects of economic, political, social and cultural life, people can hold different positions, thereby carrying simultaneously the ideas of several political directions. Based on this, it can be noted that every flow of public political thought in its pure form exists only in classical theoretical formulation. 
In practice, there is a combination of the most important elements of liberalism, social democracy, conservatism, etc., their interdependence, and this is a characteristic feature of the modern world system as a whole, focused on universal ideas, ideals and principles.

\section{Modern value foundations and principles of the three world ideologies: liberalism, social democracy, conservatism}

In the history of ideologies, there has always been a dispute that one or another ideology can more deeply understand and assess social phenomena and processes occurring at a particular historical moment, and on that basis, to program and adequately use its own theoretical and practical potential, methods and technologies aimed at dynamic, balanced and progressive development of society and civilization as a whole. In this regard (and in the current conditions of social development it is clearly manifested), there are some opinions that a certain ideology is the only possible and rational in respect to a social project.

Obviously, any subject that identifies himself with this or that theoretical tradition has the right to uphold his conceptual values and principles, to claim his benefits - a natural process inherent in the worldview of individuals and their attitude to reality. The positive character of this condition is that this tendency does not allow ideological uniformity to take shape and to be entrenched, the uniformity which can lead to rather profound negative consequences, especially within the whole world system, and on the contrary, allows ideologies to restrain one another from extreme forms of manifestation and is a driving force of social evolution and real social progress.

Each ideology is guided by certain values and principles in its attitudes, outlook, and political activity. Herewith, within each modern ideology, a number of currents, trends, types and models are distinguished, where the basic values and principles are highly contradictory. It all depends on what the ideologist takes as the basis for solving a particular issue. In this respect, the author of this study believes that it would be logical to conduct a further examination of this problem, based on the general trends of each of these ideologies. And treat each ideology as a coherent ideological phenomenon.

Thus, the basic values and principles for liberalism are freedom, individualism, and equality. For modern liberalism, freedom means the real possibility of choice, which implies its developed and differentiated understanding. At this stage of development, all kinds of freedom (with a wide range of subspecies) fall within the field of view of liberalism, each of them corresponds to a particular sphere of activity. This spectrum is quite wide: worldview, political freedom, social, economic, creative, freedom of love, etc. Recognizing the contribution of liberalism to the development of 
human freedom, it is impossible to neglect the fact that in its modern dimension, it represents the world as an example of not only freedom, but also of its certain limitations that have become the dominant of social development. Liberalism defines freedom as lack of coercion, but at the same time it is limited by legal and moral law aimed at protecting the individual's and state's interests. It is the state that is to establish the balance between freedom and law within the liberal field.

Liberalism in substantiating the principles of individualism, on the one hand, focuses on the idea of the autonomous existence of each individual; on the other hand, it is based on a holistic approach whereby a person is viewed as a social being who needs to cooperate with other people, he / she focuses on his / her social environment. The principle of individualism is focused on the social protection of human rights, their dignity and sovereignty, their independence and self-sufficiency as a member of the community, their ability to withstand external influences.

A liberal understanding of equality is built not on the idea of social equality, but on the legal equality. Modern liberalism argues that people in society can be equal under the law in obtaining civil rights, in the right to property, etc., but they cannot be equal in their mental and physical capabilities. Thus, it insists that the legislation should take into account individuals equal both in origin and in ability. At the same time, providing equal starting opportunities the legislation should not restrict the rights of people who are more capable.

The basis of the social and democratic phenomenon is freedom, equality, social justice and solidarity. It is the principles of "justice" and "solidarity" that are the main peculiarities of social democracy in relation to liberalism and conservatism. In this context, the opinion of the authoritative Ukrainian researcher M. Popovych, who studies the principles of "justice" and "solidarity", is exactly relevant to those features of the ideology of social democracy that make it different from the liberal and conservative ones. The scientist points out that "pure" liberals uphold the principle of noninterference in economic life, insisting that everyone should break out of poverty - then society will be "effective", will become richer and give the poor more chances. Social democracy is sometimes willing to sacrifice efficiency in the name of justice. It seeks to avoid such a situation where success is achieved "at the expense of the weaker", at his expense. M. Popovych maintains that Western social democracies, no matter how radical their programs are, always stopped before the steps that required authoritarian consciousness. Without giving up collectivist political morality, they formed its personality-tolerant character. Social-democratic ideology demands solidarity with the poor and the weak - not only in their nation-state, 
but also on a human scale. Ignoring the actual inequality of people, the uniqueness of each individual with his talents and disadvantages, the inevitable difference in income and vital luck, social democracy stands for "justice" as "equality of rights and opportunities" for every member of society. According to M. Popovych, the principle of "freedom" means, first of all, political democracy with all individual's rights which it provides. Social democracy is no different from that of liberals - it also regards political freedoms as only part of what a person in a free society is entitled to. Political freedoms express a person's right to participate in governing a state and society. But in addition to this right, a person must have a number of other inalienable rights ${ }^{1}$.

His opinion is supplemented by the ideas of S. Prutliak, who believes that "in the context of a rational and critical paradigm, social-democratism means a civilized level of social development. It is a conceptual definition of an open democratic society, aimed at reproducing the humanistic system of values, the culture of power and politics, the responsibility of power institutions, the legitimation of relevant structures, politicians etc. It is the values of social democracy that reproduce the specifics of a civilized society, embodying the ideals of the freedom of the individual, of the spirit, of the value of a legal social state. Social democracy sees the foundation of freedom not in private property, but in equality of rights and opportunities, in political and social protection"

It is very difficult to determine universally accepted traditional values in conservatism, since the filling of their meaning in all nations, peoples, social groups, etc. is different and depends on the historically formed mentality, national and cultural, spiritual traditions of a particular socio-political community, the formation of a social and political community fundamentals, collective identity, etc., on the particular circumstances (conditions) in which the political decision is made. Therefore, there can be no single approach to understanding the traditional values. And at the same time, based on scientific works that give an idea of conservatism and a wide range of its values, the key things are stability, law, order, and tradition. In this context, the opinion of the academician of the NAS of Ukraine B. Danylyshyn seems quite relevant, he believes that "the philosophy of conservatism emphasizes the importance of stability as the embodiment of order and tradition. Freedom is also important

1 Попович М. Соціал-демократична позиція в умовах України. Лівоцентристська перспектива України : збірник експертних матеріалів. URL: http://www.online.km.ua/ igs/leftcent.html\#0

${ }^{2}$ Притуляк С. I. Український вимір світової соціал-демократії періоду постбіполярності: пошук оптимальної моделі взаємодії. Прикарпатський вісник НТШ : наук. журн. Івано-Франківськ. Думка. 2013. № 3(23). С. 121. 
here, but not as a central value (which is characteristic of liberalism), but as a condition for providing order. Similarly, order and tradition in the modern philosophy of liberalism are considered a prerequisite for the realization of individual freedom. The same applies to private property, whose importance is justified by conservatives and liberals. But with the difference that for the former it is a condition of order and stability, for the latter it is a condition of free human development" 3 .

Undoubtedly, liberalism, social democracy, as well as conservatism and other political directions, have an inherent appeal to established traditions, social morality and culture. Yet, in this matter, conservatism is notable for its adherence to historical time, which is justified in the organic synthesis of the past, present, and future prospects, based on the principle of socializing existing experience and preserving historical traditions.

Theoretically, the state, the people and other social subjects can be considered without a historical past, but practically their real existence and dynamic development is impossible without this aspect. Modern liberals are aware of this fact because in the history of the liberal ideology existence, they have often built its ideal constructions, leaving behind historical, national traditions which led to its discrimination.

Modern conservatism recognizes the universality of such concepts as individualism, personal freedoms, human rights and obligations, equality under the law, it upholds the ideas of free competition, free market, social reforms, welfare state, state regulation of the economics, while advocating for state intervention into a market economics and promoting entrepreneurship etc. O. Kuleshov's opinion seems to be correct in this context, he believes that "modern conservatives, apparently, under the influence of liberal demands of personal integrity, allow for value compromises. Nevertheless, the possibility of compromise is assessed differently. However, the prevailing trend in modern conservatism is the doubt that value compromises can be reached. Differently interpreted values are incomparable, but it does not imply a need for tolerance, but for upholding one's own values. What distinguishes modern conservatism is the sense of the limit behind which compromises lead to the loss of basic social values and social order in general. Conservatism is fundamentally opposed to fashionable theories of value pluralism, moral relativism and multicultural tolerance. This position leads to the acceptance of the inevitability of conflict in today's world. Admittedly, historical optimism is not characteristic of modern conservatism"4.

3 Данилишин Б. Лібералізм і консерватизм - Інь і Янь. Дзеркало тижсня. Вип. 45. № 1220, 24 листопада - 30 листопада. URL: https://dt.ua/gazeta/issue/1176

${ }^{4}$ Кулєшов О. В. Проблема цінностей в сучасному консерватизмі. Вісник Черкаського університету. Серія Філософія. Випуск № 31 (324). Черкаси, 2014. С. 26. 
Therefore, based on the foregoing we can claim that among the wide range of value propositions in each ideology, in reality, there are several basic values that are recognized by the majority of people in democratic societies and integrate ideologies that are amenable to analysis. It is freedom, equality, order, tradition.

Freedom is understood as the possibility of each person's selfdetermination and the right to individual self-development. In this case, it is not only about the freedom of the individual, but also about political freedom - the right of the individual to participate in governing the state and society. The constitutional consolidation of freedoms and rights, their regulation and protection by the law, and the provision with the property are the necessary conditions for the free choice of the vital position of every citizen. In doing so, the legal aspect of freedom must necessarily be integrated and commensurate with the principles of personal responsibility and obligation. In the economic sphere, these are free market relations.

The very concept of economics implies a process of social and political regulation in the totality, and it is the sphere of social development that allows to fully reveal the potential opportunities and needs of the individual, where he can most fully realize and improve himself.

At the heart of the modern economics is its key factor - technological progress, which leads to the growth of production, activation of trade flows, financing and investment, expansion of consumption and markets, activation of labor migration, competition and productivity, changes in its nature, etc. Participants in the economic process (people directly) are no longer seen simply as a workforce, but as direct creators of their interests and needs.

The formation of such economic structures is formed under the influence of information technology development. The information space allows a person to deepen the process of knowledge, which is the basis for the formation of intellectual capital, on which the progress in the economics and the well-being of modern society depends in this or that way.

Based on the idea of equal value of each person, the category of equality is understood as equality of initial opportunities, and not equality of the distribution of income, equality of rights and opportunities for every member of society and equality of all members of society under the law, while not ignoring the actual inequality of people. More broadly, it is social justice.

True order in society and the state can be achieved based on the rule of law.

At the same time, it should be noted that the issue of freedom, equality, law, justice and their interrelation among liberals is developed much wider and deeper than in other directions of socio-political thought.

Tradition does not exist on its own and is not separate from certain time. This is evidenced by the fact that every created imperative, a phenomenon 
(including ideology), is natural or artificial in the traditional way for the particular era in which it was formed. And, in the process of succession, it does not lose its significance in the course of the historical development of society, civilization as a whole, thereby acquiring the content (including in the concept) of tradition. Tradition is not a constant, because it constantly changes its socio-cultural content, depending on social reality and the laws of social development.

In addition, it should be borne in mind that each ideology has its own vector of awareness of social life, which is formed based on its common values, priorities, functions and tasks, and in each of them they are sufficiently structured, therefore, they cannot be identical and create a whole ideological field.

The peculiarity of modern liberalism is that in its theory, it does not create new directions and trends, but proposes adequate projects to be solved based on the needs and priorities of time, which are connected with the formation of the foundations of a new society. This is where its relevance and advantage lies.

The peculiarity of modern social democracy is that it responds very quickly to external changes and integrates them into its doctrine in the shortest possible time.

As far as conservatism is concerned, it should be noted that it has traditionally been regarded as a special type of socio-political thought that appeals to the protection of values, institutions, social structures existing at a specific historical period, etc. If such narrow understanding of conservatism was followed, it would have lost its viability, its theoretical and practical relevance. However, its ability to respond to changes in civilizational development makes it possible to claim that this ideological phenomenon is moving and revolutionary. Therefore, it is capable, like other ideologies, of changing its internal attitudes and positions. Thus, the content of conservatism also changes.

Undoubtedly, conservative ideology, in particular, as Ukrainian researcher V. Slobodian believes, feels considerable pressure of the historical past and political present, which causes a certain transformation of the main ideological nucleus. But despite this, conservatism is characterized by certain dominants. Unlike the other two major ideological systems - liberalism and social democracy - conservatism is an anti-progressive philosophy whose methodology is not philosophical theism, but some form of rationalism. Conservatism is seen as a phenomenon of the Christian socio-cultural worlds. As a phenomenon of society's political life, conservatism makes it possible to involve the potential of the public masses in the process of state-building due to understanding its cultural identity and its own historical path of political development ${ }^{5}$.

5 Слободян В. Консерватизм як ідеологія державотворення: етапи становлення. Державне управління та місиеве самоврядування. 2015. Вип. 3. С. 70. 
The ideas about the values, fundamental foundations and goals of human development are constantly changing, and so is the evolution of ideologies. In this regard, it is possible to say that the modern "global world" diminishes the existence of a particular ideology, which was difficult to see in the second half of the twentieth century. Thus, every political phenomenon began to shift into new qualities and acquire new kinds. Thus, from the beginning, it is necessary to ask questions about the criticism of mass activity, its certain groups and individuals.

\section{Modern evolutionary changes in the world political nd ideological doctrines}

The tendencies of modern changes in the worldview constructions of liberal, conservative and social-democratic ideologies in a number of normative values and principles were caused by the fact that the second half of the twentieth century was clearly marked by their ideological decline. As a result, prophecies (which came largely from ideological opponents) have emerged predicting that these ideologies were losing their ideological basis and relevance, which had to inevitably result in their disappearance. In the last decades of the XX - the beginning of the XXI century, the processes of posteconomic transformation and the global cardinal changes that took place in the society led to the desire of a number of ideologies to defend their priority. Based on this, new ideas and concepts about the "end of history", "end of future", "end of politics", "ideological crisis", etc. appeared at the end of the twentieth century, and were actualized at the turn of the last two centuries.

There are a lot of ideas about the ideological crisis, but the essence of the question is to think about these hypotheses and to assess them objectively. Thus, we can say that the liberal, conservative or social-democratic ideology at a certain stage of historical development in a particular country did not have a leading position any longer. And there are enough reasons for this, but the key reason is that the subjects who used it in the context of a particular reality, could not always coordinate their actions adequately to the theory and practice of the ideology itself, and based on this develop new models and mechanisms for implementing its ideas and positions.

Modern scientific provisions have a rooted idea that at a certain stage of the society development, ideology is losing its importance for the further public use and development of the individual, society, and the state. Thus, it either suspends or stops the process of its large-scale existence in order to undergo significant correction again, but in a new perspective. For example, communist ideology ceased to exist as an ideology for a large part of the world-wide population, but it received its renewed continuation in sociopolitical associations (parties, unions, etc.). In the same perspective, we can 
talk about a number of other ideologies. In particular, regarding the political and ideological doctrines considered in this study, it can be noted that a number of their values, norms, ideas and provisions have received their new justification and practical implementation in other ideological models.

In this regard, we cannot claim categorically that we observe the "collapse", "end", "fall" of a particular historical process, or that according to the laws of nature, "it is only the universe that is eternal", and all other dimensions are subject to cycles, changes, transition to other states, and most of all it is to do with ideological projects created by man and his own society, and which are in constant search. And partly in the search for the best. However, such searches do not always produce positive results. But the best that was worked out in this process has still remained and enriched, even when choosing a different path.

Based on this, it should be noted that the theoretical justification of the ideologies under consideration cannot be defined by terms such as "crisis", "end", etc., which can, in fact, be attributed to its ideological and practical state, since scientific knowledge, which has been subjected to continuous updating, supplementing and correction, is a constantly developing and improving phenomenon which can be a basis for any ideology. This, in fact, is evidenced by the whole process of development of world political and ideological doctrines, both in theoretical and practical application. Thus, their ideological decline should be regarded as the starting point of the process of modernization changes in themselves and in treating them.

So, political practice has shown that despite certain difficulties connected with the application of approaches and methods established in the era of industrialism, each of them at the end of the last century was able to comprehend the ineffectiveness of some of its traditional principles and thereby modernize itself in accordance with the objective situation and the tendencies of an ever-expanding democracy. Thus, the standard of ballancing the three leading ideologies of history and modernity is democracy, and there is a task of rethinking the previous hard confrontation between the ideologies mentioned above.

Modern socio-political science believes that the democracy of the present model should, above all, be regarded as an ideal that serves as a guide for the society development. On this basis, within the framework of democratic principles and rules, modern political and ideological doctrines - liberalism, socialism, conservatism etc. build their program provisions and carry out practical activities. Such changes occurring in the ideological settings of these political phenomena lead to the fact that in the process of crossing the boundaries of the democracy sector with the ideology of liberalism, socialism, conservatism, etc., a new form (type) of ideology is created. As a result of the synthesis of democracy and liberalism, there was an ideological unification of 
these constants in a liberal democracy, which combines the political principles and rules of the first, and the legal and economic principles of the second ideological phenomenon; between democracy and socialism appears social democracy with principles of humanistic, progressive development of society and socially oriented economics, in the course of interaction of democracy with conservatism the following takes place: appeal to traditions and values of the past in order to get an answer to the key issues of nowadays, the need for modernization changes at the level of human consciousness, motivation for activity and behavior.

In modern conditions of dynamic development of society and civilization, some tendencies of convergence between liberalism, social democracy and conservatism are traced, which determines the character of evolutionary changes in their political and ideological doctrines. This is not a new historical fact, born by modern times. The apparent convergence of conservatism with liberalism can be seen even in the postmodern era, whereas so far in all spheres of socio-political life (politics, economy, religion, art, culture) there had been a pronounced opposition between them that emerged from the very essence of traditionalism and innovativeness itself since conservatism relied on the first and liberalism on the second. In this era, liberal ideas were filled with the conservative content, conservative ideas - with the liberal content. Tendencies of liberal and social-democratic ideologies' convergence in their vector direction began to appear in the first half of the twentieth century and its subsequent period, when the issues of socio-political and socio-economic regulation of social relations, national sovereignty, strong and responsible statehood, reforms, appliance of the institutional approach to solving emerging problems etc. were actualized. And at the end of the twentieth century, due to the global changes in the geopolitical space, the transition from industrial to post-industrial society, changing of the emphasis by means of accumulating the processes of social development, no longer within national states, but at the global level, changes in the prospects of civilization which gave rise to the problem of choosing a political orientation adequate to the demands of the times, interests and expectations of the society and many other circumstances that significantly changed the whole world system as a whole, this fact became dominant.

Social democrats and conservatives, based on the liberal conception of the human personality value, focus their attention on the development of human individuality, the social significance of their rights and freedoms, needs, way of thinking and behavior, creative opportunities, responsibilities, which in their individual meaning are a prerequisite for the collective phenomenon formation. Moreover, in the present circumstances, collective values are inferior to individual values, and individuals join certain communities, groups, etc. only to realize and defend their own interests. Thus, the concept of collectivism as such loses its 
value and importance and gives way to a new form of relations - territorial communities, which both social democrats and the liberals appeal to, this extends the possibility of practical interaction of the two ideologies.

Meanwhile, social democrats have not completely renounced the role of a collective phenomenon in society (renouncing its importance and role in the theory and practice of Soviet socialism), and conservatives - the importance of the community (family, ethnicity, nation, society, etc.), explaining it by the fact that complete individual's self-development and self-expression, his spiritual and cultural formation are hard to imagine without them. In this case, conservatism is closer to the socialist tradition, since both trends defend the principle of collectivism, which opposes individualism, the priority role of the state in relation to other social subjects (personality, society), the idea of the society unity (on the basis of nationality, ideality, government goals, etc.).

However, when it comes to the realization of modern liberalism in the community (as a unity of citizens), one cannot help but admit that liberalism is aware of its importance from certain points of view. Assessing the motives for successful society development (stable balanced economics with high efficiency of productivity, high standard of living, balanced relations between the state and civil society, etc.), liberals are convinced that the implementation of projects and achievement of the set goals, the use of management technologies, the use of management and other forms are possible as a result of public consent and informed choice of citizens.

Based on the above-said, it should be noted that the liberalization of the ideology of social democracy and conservatism brought these political phenomena to a change of priorities, a positive assessment of some aspects of individualism and collectivism, and updated the interpretation of these categories.

At this stage of its existence, the ideologies we are analyzing have diverged from their previous methods and mechanisms used in meeting the needs of social groups and their organizations and in addressing emerging issues. Liberals, social democrats and conservatives are convinced that the demands put forward by society can be solved and implemented by peaceful means, by gradual evolutionary transformations. The transition to a more sophisticated social system should not be forceful, but should be gradual and transformational. Thus, based on Marxist theory, social democrats abandoned the idea of conducting social changes and changes in the system by means of social and political revolutions. At the same time, conservatism, as a supporter of evolutionary development and change (which makes it closer to liberalism), in contrast to the explicitly categorical demand for a return to the old order that underlies reactionary political doctrines, is philosophically and socially political phenomenon, which is evolving and changing; although it manifests itself differently in certain situations, but still it follows the tendencies of social progress assessing objectively the prospects for social development. 
At the end of the twentieth century, well-known reasons and a number of specific problems brought the social state to crisis. However, neither neoliberalism nor neo-conservatism, which sought to take the place of liberalism and correct all its shortcomings, nor the changes that took place in a number of political systems and in the structure of the bipolar world, solved the problems imposed on the social state (increased unemployment, low salaries, poverty, illiteracy, social insecurity of certain categories of population, serious demographic changes, unprecedented tension of social contradictions and conflicts, etc.). In this regard, scientists and politicians are tasked with finding the best ways to solve social problems. Within these trends, representatives of the three main ideological and political movements (liberalism, social democracy, and conservatism) proposed a new concept of a welfare state. Modern European liberals and social democrats, while acknowledging the shortcomings of the "welfare state", did not abandon it, but replaced it with "welfare society". In fact, decentralization of the state functions, in particular, in the realization of their social and political sphere, and their transfer to regional, local authorities and civil society, is recognized as necessary. These social and political entities, in accordance with the provisions of decentralization of governing structures, have the right to voluntarily fulfill their statutory powers and functional responsibilities. Thus, state intervention in all spheres of social life becomes superfluous, therefore, the state becomes a coordinating and regulating body. Moreover, it abandons the state control over economics that is common to the two ideologies under consideration.

The welfare society offers an active role of the welfare state in creating the conditions that allow each individual to self-actualize and conduct their own activity.

Each of the ideologies under study offers its own model of the welfare state. In this context, we consider quite correct the opinion of the national researcher D. Skovronsky, who notes that the liberal model of the welfare state is characterized by the principle of individualism, which assumes everyone's personal responsibility for their own destiny, the destiny of their family. In this case, the role of state structures in the implementation of social policy is minimized. Its main subjects are individuals and various nongovernmental organizations - social insurance funds and associations. The conservative model is based on the idea of introducing social differentiation in society. In this model, property inequality is a normal phenomenon, and the main task of the state is to redistribute income by means of flexible tax policy, to provide compensation for those who need it. The social-democratic model, as D. Skovronsky argues, aims at preventing sharp differentiation of income levels. Social guarantees are provided both by the state and non state structures. The social policy of the state is aimed at providing all citizens with a job. The formal absence of unemployment forms a stable tax system. The level of taxation is better than in the liberal model. 
This enables the state to redistribute the centralized fund, providing citizens with social assistance. The directions of social policy are directly derived from the social rights of the population ${ }^{6}$.

At the same time, the peculiarity of the modern approach of these ideologies concerning the social state is that the state social expenditures, which significantly weakened the institution in the 1970s - early 1980s, are delegate to the society and individuals. In this regard, the welfare state focuses its efforts on investment in human and social capital, which does not involve provision of a job, but provision of education, the possibility of obtaining new professions and the creation of new jobs.

Thus, modern social democrats in social development carry out a process of transformation from a "state of assistance" to a "state of social investment", the latter is also inherent in modern liberalism.

These changes also imply a change in the nature of work itself. In turn, with the change in the nature of work, the nature of ownership also changes. Social democrats, after moving to a position of macroeconomic policy that clearly recognizes the importance of the private property institution, have thus affirmed the idea of recognizing an inalienable human right - the right to property that is legally enshrined.

The same positions are supported by a contemporary conservatism. However, it should be noted that a number of provisions that form the basis of the Western model of the welfare state were elaborated in the process of social-democratic and liberal ideas' convergence.

The synthesis of liberalism, social democracy and conservatism depends on the ratio of the components of ideas, values and principles of their ideologies, on the conditions and needs of social reality, the subjects who study and use this direction.

A vivid example of the synthesis of these ideological phenomena's traditional political values in the history of their existence, is the new ideological form that has emerged in this process - neo-conservatism.

This socio-political phenomenon was generated by a specific historical situation and globalist processes in the middle of the second half of the twentieth century. It came about when traditionally conservative, liberal and social-democratic principles, norms and attitudes, inherent in all their ideological theory and practice, and used directly in the process of reforming the world system in the twentieth century, lost their effectiveness, and their methods did not meet the requirements of the time.

${ }^{6}$ Сковронський Д. М. Сучасні моделі соціальної держави. Вісник Національного університету “Львівська політехніка”. Серія: Юридичні науки : зб. наук. праць. 2016. № 850 . C. $265-267$. 
Neo-conservatives united on the basis of the objective need to use radical methods and means to undertake economic recovery, based on technological progress which implies state intervention in this sector and greater freedom of market relations, free competition and private property. Criticizing the state's virtues in the social sphere, they suggested that the public sector of the social services be partially privatized. Unlike liberalism and conservatism, special attention is paid to the internal and external policies of the state. In political sphere, they give priority to pluralism, the protection of citizens' rights, the protection of individualism, the rights of private property, the pursuit of traditional specific national and ethnic values along with the universal values, the state is seen as the guarantor and defender of law and morality, it must provide freedom and privacy. Neo-conservatives prefer authoritarian principles, oppose excessive democratic freedoms, for domination of the state they imagine, for using forceful methods in solving socio-economic and political problems, etc.

At the same time, its novelty is relative, because it is based on the ideas and principles of classical conservatism, liberalism and social democracy. Its peculiarity is the reaction to their miscalculations and mistakes.

On the other hand, based on its contemporary social orientation, it is increasingly approaching social democracy, which is based on the principles of solidarity and justice. And finally, there are a number of central provisions of conservatism distinguished in its political orientation: the priority of subordination of the individual to the state and provision of the political and spiritual unity of the nation, the transition to innovation by means of a deep understanding of the possible consequences of action, upholding the existing state and social order, stability, social institutions (strengthening families, churches, voluntary organizations, etc.), which are the basic units for moral, spiritual, cultural formation of the individual, etc.

Therefore, evolutionary changes in the world political and ideological doctrines in the present conditions of dynamic development of society and civilization are manifested at the level of mutual adjustment and restraint. These manifestations are achieved provided that each of the ideologies enters the relations of this kind with another ideology as an opponent, based on the specific needs and conditions of the state of society and civilization. At the same time, what is important is the internal motives of each ideology which underlie the reaction to the modernization processes and their results (both positive and negative), the degree of effectiveness and influence on the political and the whole spiritual climate of the world system, the constancy of authority as their own and competing ideology; awareness and determination of one's position in an ideological hierarchical structure in a particular historical period. In this regard, it is of particular importance to evaluate one's own principles, goals and objectives, as well as opposing ideologies. 


\section{CONCLUSIONS}

The history of political thought shows that the main differences between liberalism, social democracy and conservatism lie in the assessment of the paths to the goal, in their obligations towards a particular social entity, in the assessment of current changes, in the scale of values, in priorities.

At the same time, based on the fact that ideology, in its nature, is represented by ideological, worldview constructs that are the product of the human mind, thinking style, emotional and psychological orientations and priorities of the individual and his practical activity, determined by social objective and subjective motives, it turns out that it is constantly subject to change, which, in turn, leads to new forms of thinking. Thus, no ideology can in its singularly isolated existence, nor in their quantitative unity, constitute a universal, complete theoretical model. Definitely, a purely liberal, social-democratic, conservative and other models of social order and dynamic development of society and civilization as a whole do not exist. This is mainly due to the fact that the very conditions and peculiarities of the formation, development and practical realization of the ideologies under consideration at each historical stage of social evolution, determined the process of their permeation, complementarity and interdependence, both in theoretical and practical aspects.

At present, internationally, these ideological phenomena have more common than different points, they defend freedom of the individual, economic freedom, inviolability of private economic initiative and private property, free market economics, constitutional state, the prevalence of laws and their value, etc. Freedom for them is not considered to be an absolute value, because its existence is allowed only within the necessary limits and responsibilities.

At this stage of their development, the analyzed ideologies have diverged from their previous methods and mechanisms used in meeting the needs of social groups and their organizations and addressing the emerging issues. Liberals, conservatives, and social democrats are convinced that the demands put forward by society can be solved and implemented by peaceful means, gradual evolutionary transformations. The transition to a more sophisticated social system should be not forceful, but gradual and transformational.

\section{SUMMARY}

The basic modern values and principles of the three world ideologies, namely, liberalism, social democracy and conservatism, have been identified and analyzed. It has been revealed that the fundamental values and principles for liberalism are freedom, individualism, equality; freedom, equality, social justice and solidarity are at the heart of the social-democratic phenomenon; for conservatism, the main ones are stability, law and order, tradition. It is noted that among the wide range of value orientations in any ideology, there are in reality several basic values that are recognized by most people in democratic 
societies and integrate ideologies that are amenable to analysis. The main factors that led to the modern orientation of the world political and ideological doctrines' evolution were analyzed. The basic changes in their outlook constructions which occurred in a number of normative value provisions and principles, were described. It was concluded that a lot of principles, attitudes, values, norms of complex worldview constructions, which used to be a field of brutal struggle, underwent significant historical changes in the course of human civilization development and at the present stage are closely intertwined and have become a common property. It is emphasized that in spite of the tendencies of convergence of liberalism, social democracy and conservatism in the ontological sense, there are significant differences between them.

\section{REFERENCES}

1. Попович М. Соціал-демократична позиція в умовах України. Лівочентристська перспектива Украйни: збірник експертних матеріалів. URL: http://www.online.km.ua/igs/leftcent.html\#0

2. Притуляк С. I. Український вимір світової соціал-демократії періоду постбіполярності: пошук оптимальної моделі взаємодії. Прикарпатський вісник НТШ : наук. журн. Івано-Франківськ. Думка. 2013. № 3(23). С. 119-120.

3. Данилишин Б. Лібералізм і консерватизм - Інь і Янь. Дзеркало тижня. Вип. 45. № 1220, 24 листопада - 30 листопада. URL: https://dt.ua/gazeta/issue/1176

4. Кулєшов О. В. Проблема цінностей в сучасному консерватизмі. Вісник Черкаського університету. Серія Філософія. Випуск № 31 (324). Черкаси, 2014. С. 21-28.

5. Слободян В. Консерватизм як ідеологія державотворення: етапи становлення. Державне управління та місиеве самоврядування. 2015. Вип. 3. С. 62-71.

6. Сковронський Д. М. Сучасні моделі соціальної держави. Вісник Національного університету “Львівська політехніка”. Серія: Юридичні науки : зб. наук. праць. 2016. № 850. С. 264-271.

Information about the author: Natalia Hedikova,

$\mathrm{PhD}$ in Political Sciences, Professor, Professor at the Department of Political Science and Law,

State Institution "South Ukrainian National Pedagogical University named after K. D. Ushynsky" 26, Staroportofrankivska str., Odesa, 65020, Ukraine 